\title{
Comparative Study of Grinding Machines Processes on Laboratory Scale and Production Scale in the Printing Ink Industry
}

\section{Studi Komparasi Proses Grinding Mesin Skala Laboratorium dan Produksi di Industri Tinta Cetak}

\author{
Khanif Eko Prasetyo a,1,*, I Dewa Gede Arsa Putrawan ${ }^{\mathrm{a}, 2}$ \\ ${ }^{a}$ Program Studi Teknik Kimia, Fakultas Teknologi Industri, Institut Teknologi Bandung, Jalan Ganesha 10 Bandung 40132, Indonesia \\ ${ }^{1}$ alkhanif@gmail.com*; ${ }^{2}$ idewa@che.itb.ac.id \\ * corresponding author
}

\section{ARTICLE INFO}

Article history

Received June 20, 2019

Revised January 14, 2020

Accepted February 21, 2020

Keywords

grinding

pigment

ink

dispersion

population balance

\section{ABSTRACT}

Grinding is a common process in the ink industry. This process is required to achieve a particular particle size based on specifications. To achieve an optimal condition in grinding, exploration processes are needed. However, an exploration that commenced in the production scale will require a lot of energy and resources. This research objective is to build mathematical modeling and correlate processes of laboratory and production scale grinding. The modeled result which developed in a laboratory scale is expected to be implemented on a production scale, thus exploration processes can be commenced on a laboratory scale with minimal cost. Mathematical modeling is simulated in Matlab®, while population balance is the bases of calculation. This research found that simulation can represent observation data. A correlation also formulated to predict the production scale grinding from laboratory scale evaluation.

This is an open access article under the CC-BY-SA license.

\section{Pendahuluan}

Tinta cetak adalah cairan atau pasta yang di dalamnya terdapat pewarna. Tinta cetak memiliki fungsi untuk membentuk suatu desain, memberikan perlindungan pada permukaan substrat dan memberikan fungsi dekoratif pada substrat di mana tinta tersebut diaplikasikan [1].

Komponen utama tinta cetak adalah pewarna dan larutan resin. Pewarna dapat berupa pigmen yang tidak terlarut dalam media atau dye yang terlarut dalam media. Dalam proses cetak, media larutan resin harus bisa berpindah dan mengikat pewarna ke dalam substrat. Sifat-sifat dari hasil cetak dipengaruhi oleh kualitas pewarna dan media larutan resin. Salah satu parameter penting dari tinta cetak yang baik adalah ukuran partikel yang seragam dan berada dibawah ukuran partikel tertentu [1]. Salah satu proses yang dilakukan untuk mencapainya adalah dengan proses grinding.

Grinding adalah proses penghancuran padatan untuk mendapatkan ukuran partikel yang lebih kecil. Dalam konteks tinta cetak proses grinding yang terjadi lebih tepatnya disebut sebagai dispersi. Pigmen yang akan digunakan dalam tinta dapat mengalami aglomerasi sehingga proses grinding diperlukan untuk mendispersikan pigmen ke dalam media larutan resin [2].

Tujuan dari proses grinding adalah untuk memecah aglomerat pigmen secara mekanis sehingga seluruh permukaan dari setiap partikel terbasahi oleh media larutan resin. Partikel pigmen yang saling bergabung atau menempel harus dipisahkan sehingga bagian dalam permukaan dapat terbasahi dengan baik [2]. 
Salah satu perusahaan yang bergerak di bidang tinta cetak menggunakan beberapa alat grinding dalam proses produksinya. Dua dari alat tersebut adalah mesin grinding Micromedia X-3 (MMX-3) dan Lau Disperser. MMX-3 adalah alat grinding jenis beads mill skala produksi dengan kapasitas 1,2 ton per batch [3]. Sedangkan Lau Disperser DAS H-TP 200-K adalah alat grinding skala laboratorium jenis attrition mill (shaker) dengan kapasitas 200 gram per batch dan dapat menampung beberapa batch hingga $20 \mathrm{~kg}$ [4]. Kedua alat grinding diatas mempergunakan media grinding yang sama yaitu beads. Sejauh ini tidak terdapat hubungan yang memadai dari kedua alat diatas. Kelebihan mesin skala laboratorium terletak kepada biaya material dan energi yang murah dalam operasinya, sehingga hubungan yang memadai antara kedua mesin grinding tersebut dapat mengurangi proses trial \& error pada skala produksi yang memakan biaya material dan energi yang lebih besar.

Tujuan penelitian ini adalah untuk menemukan metode yang tepat dalam menghubungkan karakteristik dari alat Lau Dispenser skala laboratorium dengan alat $M M X-3$ skala industri di sebuah perusahaan yang bergerak di bidang tinta cetak, yang namanya sengaja dirahasiakan. Hasil dari hubungan dijabarkan dalam suatu model matematis untuk memprediksi hasil skala produksi dari analisis skala laboratorium.

\section{Metodologi}

Neraca Populasi adalah metode yang umum dipergunakan dalam memodelkan sebuah proses grinding [5]-[12]. Metode lain seperti Discrete Element Method (DEM) dan Computational Fluid Dynamic $(C F D)$ juga dipergunakan meskipun penerapan di dunia industri masih terbatas karena sifat komputasinya yang ekstensif [13]-[15]. Dalam penelitian ini, dilakukan analisis dengan melakukan pemodelan matematika berdasarkan neraca populasi terhadap proses grinding dan distribusi partikel pada beberapa fase dalam proses grinding dari kedua mesin yang dibahas [16]. Sifat dari penelitian ini adalah pemodelan komparatif. Nilai distribusi ukuran partikel didapatkan dengan pengukuran menggunakan Laser Diffraction Particle Size Analyzer - Horiba LA-960 [17].

Hasil simulasi diharapkan menghasilkan parameter yang bisa digunakan sebagai karakter pembanding dari kedua mesin. Lebih jauh lagi parameter tersebut dapat digunakan untuk memprediksi hasil di skala produksi dari percobaan skala laboratorium.

Dalam sebuah proses grinding secara batch, neraca populasi dari partikel dengan rentang $\mathrm{k}$, dapat dinyatakan sebagai :

$$
\frac{d w_{k}}{d t}=\sum_{u=1}^{k}\left[w_{u} S_{u}(t) \Delta B_{k, u}\right]-S_{k}(t) w_{k}
$$

di mana $w_{k}$ adalah fraksi berat dari partikel dengan rentang ukuran partikel $\mathrm{k}, \Delta \mathrm{B}_{\mathrm{k}, \mathrm{u}}$ adalah breakage function dari rentang ukuran $\mathrm{u}$ ke ukuran $\mathrm{k}, \mathrm{S}_{\mathrm{u}}$ adalah selection function untuk rentang ukuran partikel $u[5]$.

Breakage function adalah parameter yang menunjukkan distribusi pecahan partikel dari ukuran tertentu ke ukuran yang lebih kecil. Tuunila menunjukkan bahwa breakage function pada bead mill dapat didekati dengan baik oleh persamaan :

$$
\Delta B_{k, u}=\left(\frac{x_{k-1}}{x_{u}}\right)^{\varphi}-\left(\frac{x_{k}}{x_{u}}\right)^{\varphi}
$$

$x_{k}$ adalah ukuran partikel pada rentang $k$, dan $\varphi$ adalah sebuah konstanta [7].

Selection function adalah laju pecahnya suatu partikel per satuan fraksi berat. Persamaan empiris yang diusulkan oleh Tuunila untuk beadmill adalah sebagai berikut:

$$
S_{k}=\frac{\alpha x_{k}^{\lambda}}{1+x_{k}^{\lambda}}
$$

$\alpha, \lambda$ dan $\varepsilon$ adalah parameter dari selection function [7]. 
Proses grinding dengan menggunakan mesin $M M X-3$ berlangsung dalam beberapa tahap. Tahap pertama adalah penimbangan, yaitu bahan baku yang berupa pigmen, resin dan pelarut dimasukkan dalam proporsi tertentu kedalam bowl 1 ton. Tahap kedua adalah proses pre-mixing, yaitu bahan baku akan di-mixing dengan kecepatan tinggi hingga tercapai ukuran partikel tertentu. Tahap ketiga adalah main grinding dengan menghubungkan bowl dengan mesin $M M X-3$ dengan konsep resirkulasi. Grinding akan dilakukan sampai mendapatkan ukuran partikel sesuai dengan spesifikasi. Tahap keempat adalah letting down, yaitu melakukan pengenceran dengan larutan resin sampai mencapai konsentrasi pigmen yang diinginkan. Proses Grinding dengan menggunakan mesin Lau Disperser, secara prinsip juga menggunakan tahap-tahap yang sama namun dengan skala yang lebih kecil. Proses yang akan diamati dalam penelitian ini hanya pada proses ketiga yaitu main grinding karena proses ini yang sangat berpengaruh terhadap kualitas akhir dari produk.

Parameter proses yang digunakan untuk mesin Lau Disperser yaitu frekuensi osilasi sebesar 660 cycle/menit dan fraksi volume bulk beads terhadap total volume sebesar 50\%. Suhu dan tekanan pada mesin Lau Disperser dijaga pada kondisi lingkungan. Sedangkan parameter proses untuk mesin $M M X-3$ yaitu kecepatan rotor sebesar $648 \mathrm{rpm}$, fraksi volume bulk beads terhadap total volume sebesar $70 \%$ dan laju alir sirkulasi sebesar $1719 \mathrm{~kg} / \mathrm{jam}$. Beads yang dipergunakan pada kedua mesin adalah jenis Zirconia dengan rapat massa 6,02 g/ $\mathrm{cm}^{3}$ dan ukuran diameter 0,6 mm.

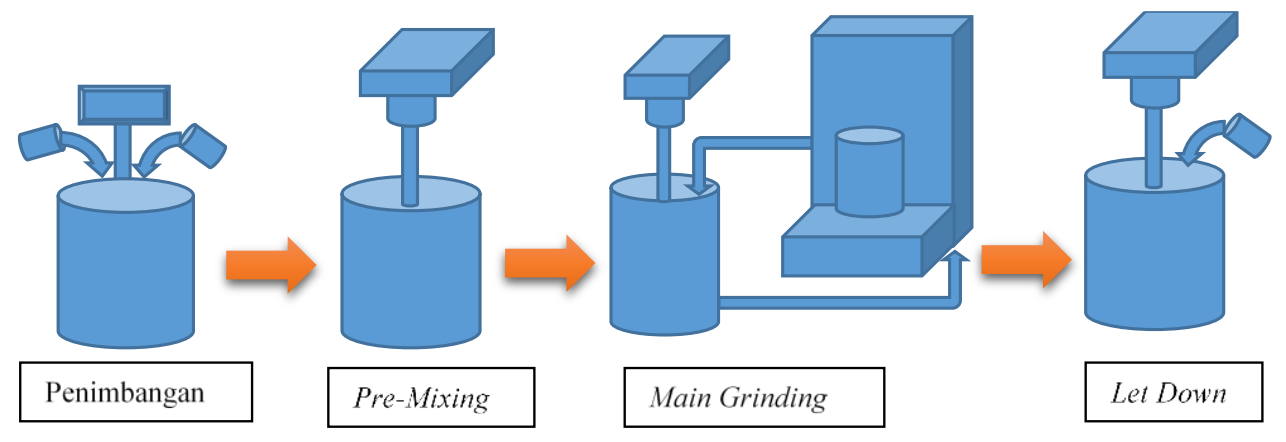

Gambar 1. Diagram alir proses grinding mesin $M M X-3$ di $P T X Y Z$
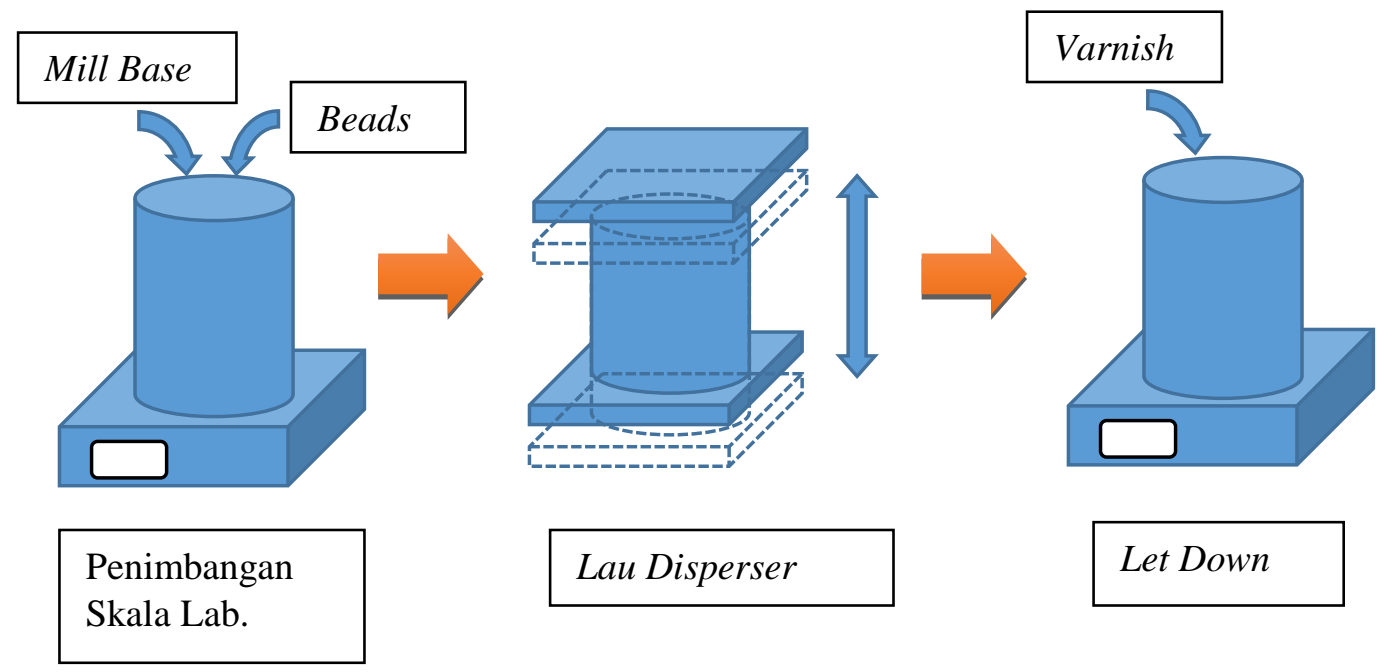

Gambar 2. Diagram alir proses grinding mesin Lau Disperser di PT XYZ

\subsection{Pemodelan Matematis}

Pemodelan matematis yang digunakan di masing-masing alat merujuk kepada fenomena yang terjadi. Mesin Lau Disperser yang merupakan mesin shaker bekerja secara batch sebagai satu sistem tertutup. Proses berlangsung secara tidak tunak sehingga ukuran partikel akan berubah sebagai fungsi waktu. 


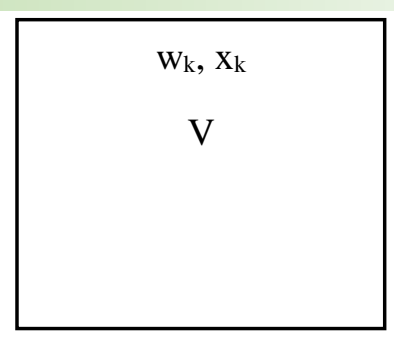

Botol Kaca

Gambar 3. Skema ruang tilik Lau Disperser

Jika $w_{\mathrm{k}}$ adalah fraksi berat partikel pada rentang ukuran $\mathrm{k}, \mathrm{x}_{\mathrm{k}}$ adalah nilai tengah ukuran range $\mathrm{k}$, dan $\mathrm{V}$ adalah volume botol maka neraca populasi untuk rentang ukuran $\mathrm{k}$ adalah :

$$
\begin{aligned}
& \text { Akumulasi }=\text { Input }- \text { Output } \\
& V \frac{d w_{k}}{d t}=V \sum_{u=1}^{k}\left[w_{u} S_{u}(t) \Delta B_{k, u}\right]-S_{k}(t) w_{k}
\end{aligned}
$$

kemudian kedua ruas dibagi dengan $\mathrm{V}$ maka persamaan menjadi :

$$
\frac{d w_{k}}{d t}=\sum_{u=1}^{k}\left[w_{u} S_{u}(t) \Delta B_{k, u}\right]-S_{k}(t) w_{k}
$$

dengan nilai breakage function dan selection function dihitung dari persamaan (2) dan (3). Di mana $\varphi, \alpha, \lambda$ dan $\varepsilon$ adalah parameter grinding yang akan dicari nilainya.

Sedangkan untuk mesin $M M X-3$, peneracaan populasi dilakukan di bowl dan mesin grinding $M M X-3$ sesuai dengan skema ruang tilik di bawah ini :

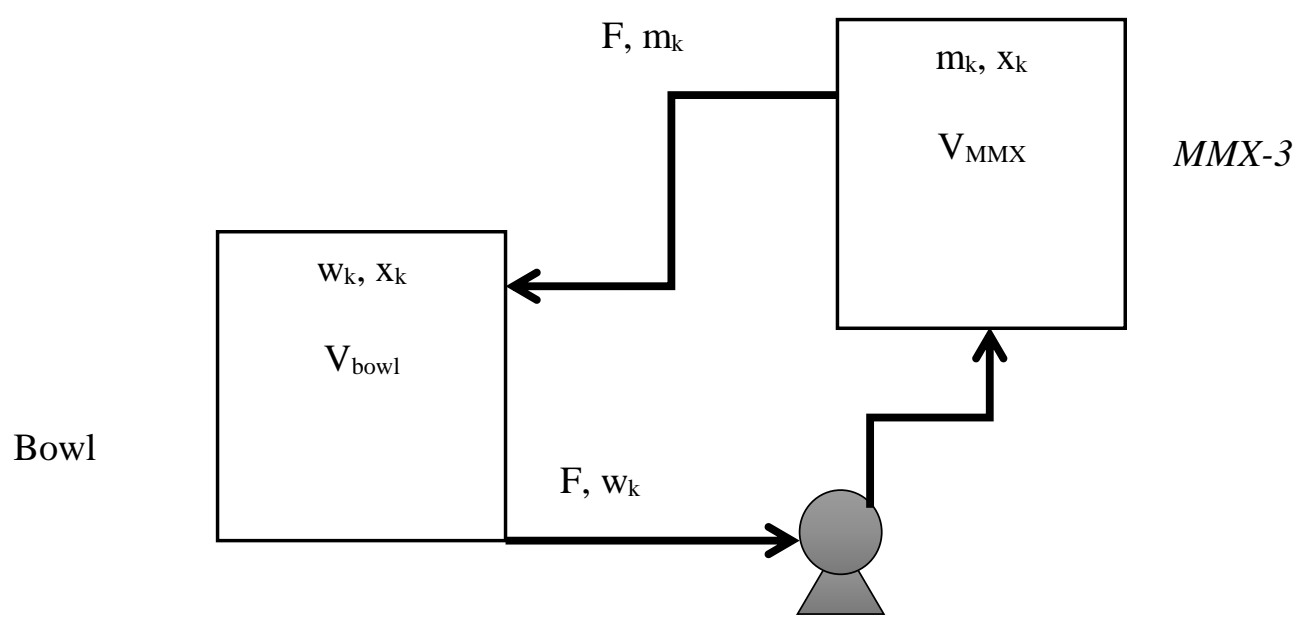

Gambar 4. Skema ruang tilik sistem grinding $M M X-3$

Berdasarkan skema di atas, sistem grinding di $M M X-3$ terdiri dari bowl yang diaduk dengan mixer dan mesin Grinding $M M X-3$. Proses pengurangan ukuran partikel hanya terjadi di $M M X-3$, sedangkan bowl hanya tempat untuk bersirkulasi. Cairan diasumsikan teraduk sempurna baik di bowl maupun $M M X-3$.

Variabel $\mathrm{w}_{\mathrm{k}}$ adalah fraksi berat partikel pada rentang ukuran $\mathrm{k}$ di $b o w l, \mathrm{~m}_{\mathrm{k}}$ adalah fraksi berat partikel pada rentang ukuran k di $M M X-3, \mathrm{~F}$ adalah laju alir volumetrik sirkulasi, $\mathrm{V}_{M M X}$ adalah volume chamber $M M X-3$ dan $\mathrm{V}_{\text {bowl }}$ adalah volume bowl, maka neraca populasi rentang ukuran $\mathrm{k}$ di bowl adalah :

$$
\text { Akumulasi }=\text { Input }- \text { Output }
$$




$$
\begin{aligned}
& V_{\text {bowl }} \frac{d w_{k}}{d t}=F m_{k}-F w_{k} \\
& \frac{d w_{k}}{d t}=\frac{F}{V_{\text {bowl }}}\left(m_{k}-w_{k}\right)
\end{aligned}
$$

Sedangkan neraca populasi pada $M M X-3$ adalah ;

$$
\begin{aligned}
& \text { Akumulasi }=(\text { Input }- \text { Output })_{\text {arus }}+(\text { Input }- \text { Output })_{\text {breakage }} \\
& V_{M M X} \frac{d m_{k}}{d t}=F w_{k}-F m_{k}+V_{M M X} \sum_{u=1}^{k}\left[m_{u} S_{u}(t) \Delta B_{k, u}\right]-V_{M M X} S_{k}(t) m_{k} \\
& \frac{d m_{k}}{d t}=\frac{F}{V_{M M X}}\left(w_{k}-m_{k}\right)+\sum_{u=1}^{k}\left[m_{u} S_{u}(t) \Delta B_{k, u}\right]-S_{k}(t) m_{k}
\end{aligned}
$$

Persamaan 6 dan 7 harus diselesaikan secara simultan dengan menggunakan nilai parameter $\varphi, \alpha$, $\lambda$ dan $\varepsilon$ yang didapatkan pada mesin Lau Disperser. Bahan yang akan dipergunakan untuk proses grinding di kedua mesin adalah campuran larutan Nitrocellulose dalam Ethanol dan Ethyl Acetate dan pigmen Carbon Black PBk 7.

\section{Hasil dan Pembahasan}

Pemodelan mesin grinding Lau Disperser dilakukan berdasarkan neraca populasi dan penyelesaian model dilakukan dengan software Matlab ${ }^{\circledR}$ dengan menggunakan fungsi nlinfit sebagai fitting modelling antara model dan data, sedangkan fungsi nlparci berfungsi untuk menghitung selang kepercayaan dari masing-masing parameter. Hasil fitting data pada mesin Lau Disperser ditunjukkan oleh gambar 5.

Parameter yang didapatkan dari hasil pemodelan mesin Lau Disperser yaitu : $\varphi=1,077, \alpha=0,033$, $\lambda=2,158$ dan $\varepsilon=1,645$ dengan nilai selang kepercayaan secara berturut-turut $0,420,0,020,0,562$ dan 2,968. Nilai $\mathrm{R}^{2}$ sebesar 0,996 dan nilai Mean of Square Error sebesar 0,038. Hasil diatas didukung dengan observasi visual yang sesuai, maka dapat diambil kesimpulan bahwa pemodelan yang dilakukan dapat mencerminkan data observasi, sebagaimana hasil yang didapat oleh Tuunila dan Petrakis [7], [10], [18].

Namun nilai parameter yang didapatkan dari hasil pemodelan Lau Disperser ternyata tidak dapat dipergunakan secara langsung pada mesin $M M X-3$. Pembuktian dengan membandingkan data observasi di MMX-3 menunjukkan ketidaksesuaian dengan nilai Mean of Square Error sebesar 0,254 .

Analisis lanjutan diperlukan untuk memahami karakter grinding dari mesin $M M X-3$ yaitu dengan melakukan fitting data pada hasil $M M X-3$ dan melihat pola yang bisa dipergunakan untuk menghubungkan karakter dengan mesin Lau Disperser. Gambar 7 menunjukkan hasil fitting data pada hasil $M M X-3$ yang menghasilkan parameter $\varphi=1,102, \alpha=1,482, \lambda=2,050$ dan $\varepsilon=1,863$ dengan nilai selang kepercayaan secara berturut-turut $0,218,0,956,0,376$, dan 3,028 . Nilai $\mathrm{R}^{2}$ sebesar 0,996 dan nilai Mean of Square Error sebesar 0,063. Pemodelan ini masih menunjukkan hasil yang diterima dengan melihat kesesuaian visual antara pemodelan dan data observasi.

Parameter yang didapatkan pada hasil pemodelan antara Lau Disperser dan $M M X-3$ disajikan pada Tabel 1. 

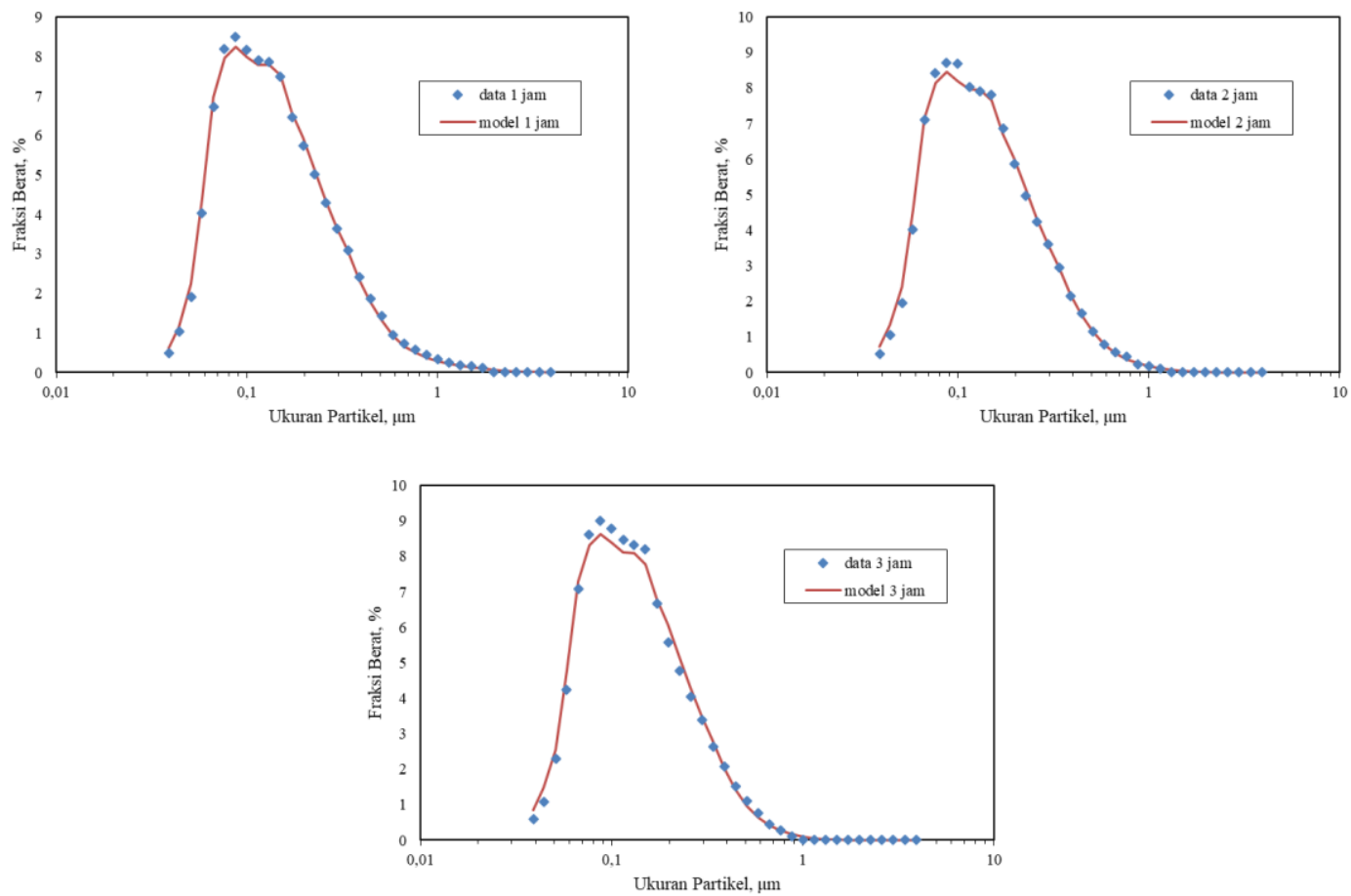

Gambar 5. Hasil pemodelan vs data Lau Disperser untuk waktu grinding 1 sampai 3 jam

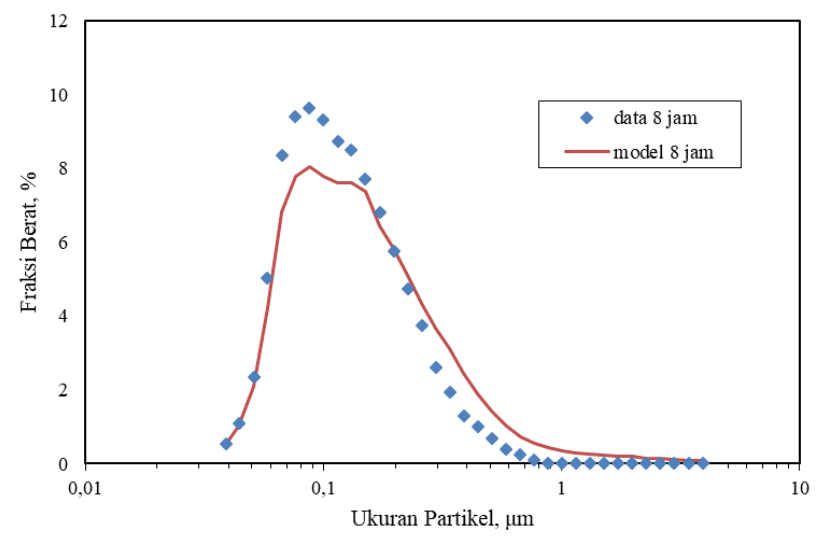

Gambar 6. Hasil pemodelan vs data MMX-3 menggunakan parameter Lau Disperser untuk waktu grinding 8 jam

Nilai parameter yang didapatkan dari proses fitting kedua mesin tidak menunjukkan korelasi yang memadai sehingga studi kaji banding dilakukan dengan mencoba membandingkan nilai breakage function dan selection function dari kedua mesin. Perbandingan nilai breakage function dan selection function dari kedua mesin dapat dilihat pada gambar 8 dan 9.

Tabel 1. Nilai parameter grinding mesin Lau Disperser dan MMX-3

\begin{tabular}{ccc}
\hline Parameter & Lau & MMX-3 \\
\hline Psi $(\phi)$ & 1,077 & 1,102 \\
Alpha $(\alpha)$ & 0,033 & 1,482 \\
Lambda $(\lambda)$ & 2,158 & 2,050 \\
Epsilon $(\varepsilon)$ & 1,645 & 1,863 \\
\hline
\end{tabular}



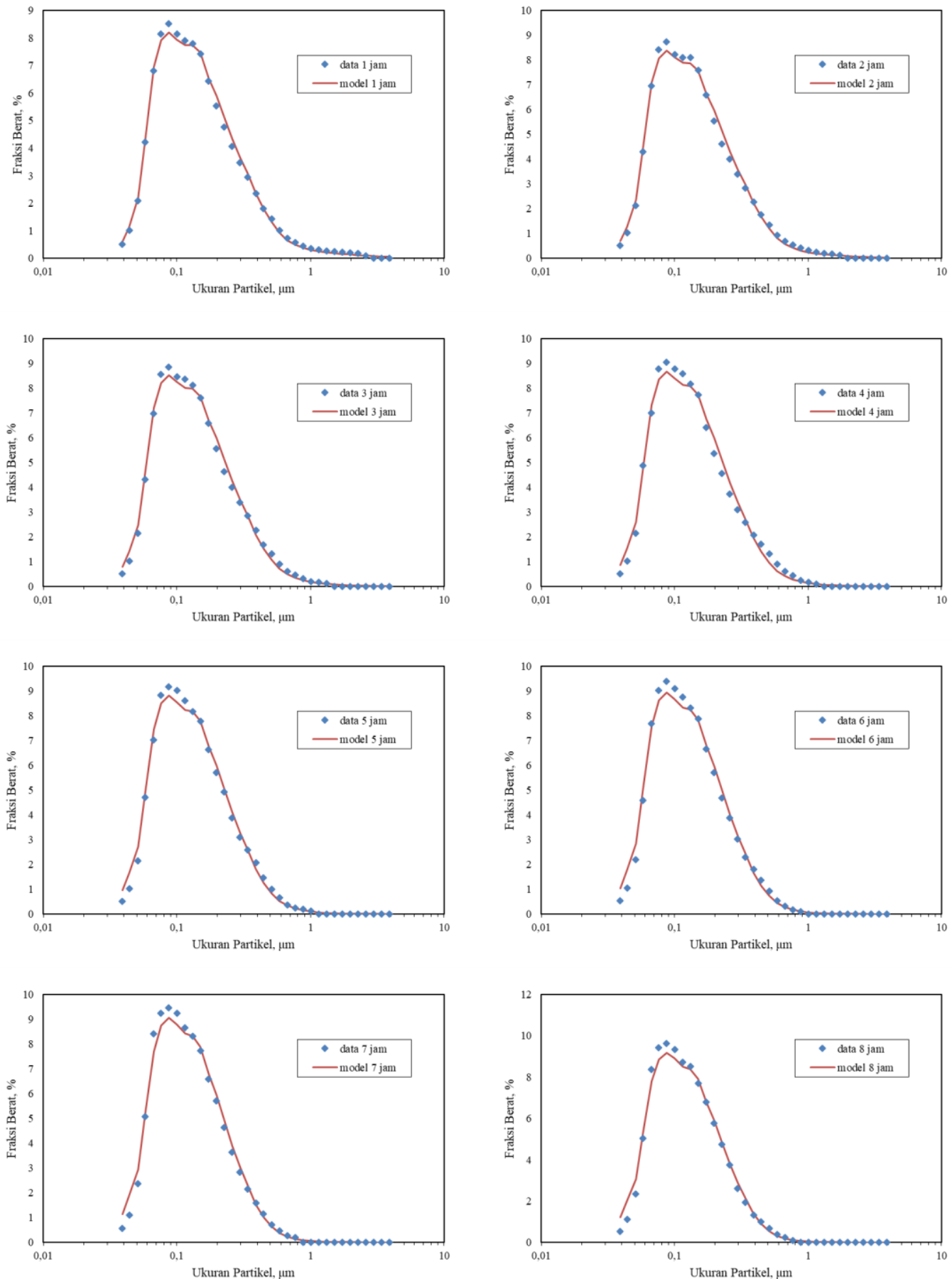

Gambar 7. Hasil pemodelan vs data $M M X-3$ untuk waktu grinding 1 sampai 8 jam

Hasil perbandingan komponen breakage function dan selection function menunjukkan bahwa tidak terdapat perbedaan yang signifikan pada suku breakage function namun cukup signifikan pada selection function. Pemodelan yang akan dilakukan selanjutnya adalah menghubungkan nilai selection function pada kedua mesin dan mengabaikan nilai breakage function. Analisis yang dilakukan pada selection function adalah dengan mencari rasio nilai antar mesin sehingga performa grinding bisa dihubungkan. Nilai rasio Selection Function antara mesin MMX-3 dan Lau Disperser didefinisikan sebagai :

$$
\operatorname{ratio}_{x}=\frac{S_{M M X x}}{S_{L A U x}}
$$


$\mathrm{S}_{M M X x}$ adalah nilai selection function mesin $M M X$ pada ukuran partikel x dan $S_{L A U x}$ adalah nilai selection function mesin Lau Disperser pada ukuran partikel x.
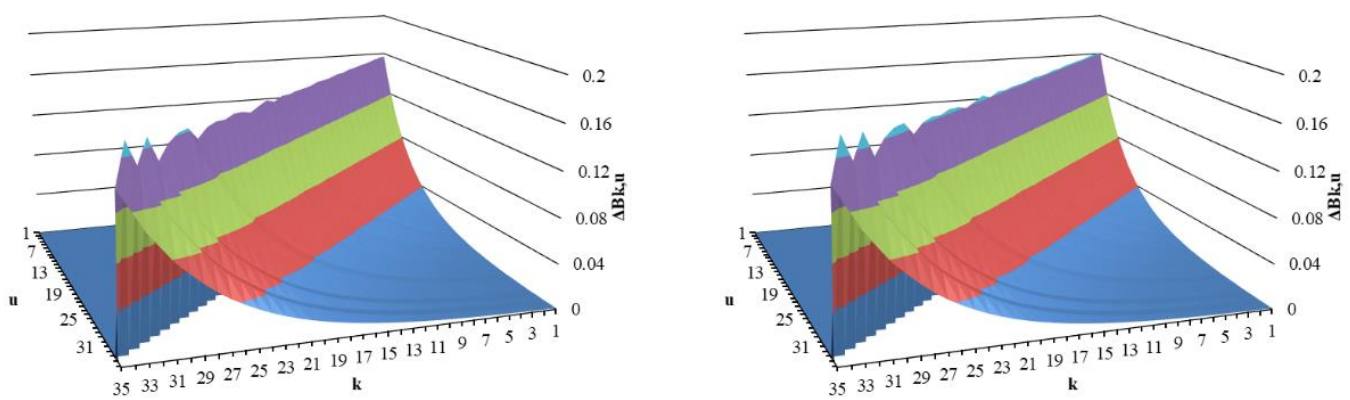

Gambar 8. Perbandingan nilai breakage function pada mesin Lau Disperser (kiri) dan mesin MMX-3 (kanan).

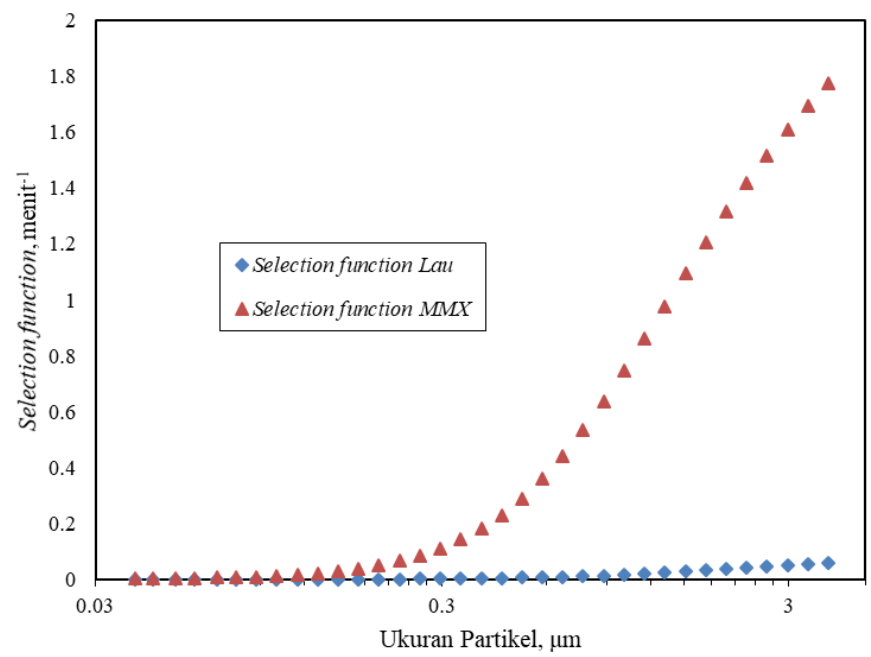

Gambar 9. Perbandingan nilai selection function pada mesin Lau Disperser dan mesin MMX-3

Modifikasi relasi antara ratioS dan x perlu dilakukan agar variabel bisa terhubung dengan baik dengan menggunakan regresi. Sebuah variabel baru yang dipergunakan untuk mempermudah regresi yaitu $\chi$ didefinisikan sebagai :

$$
\chi=\ln \left(\frac{x}{x_{\text {ref }}}\right)
$$

$\mathrm{x}$ adalah ukuran partikel acuan pada selection function dan $x_{\text {ref }}$ adalah ukuran partikel referensi, dalam hal ini diambil $1 \mu \mathrm{m}$.

Hubungan antara ratioS dan $\chi$ dapat didekati secara sederhana oleh regresi polinomial order 3 dengan bantuan Microsoft Excel®. Persamaan dihasilkan sebagai berikut :

$$
\text { ratio }=-0,360 \chi^{3}-1,955^{2}-8,370 \chi+44,285
$$

dengan nilai $\mathrm{R}^{2}$ sebesar 0,999 . Persamaan empiris yang dihasilkan diatas dapat dipergunakan sebagai alat untuk proses scale up grinding antara Lau Disperser dan MMX-3. 


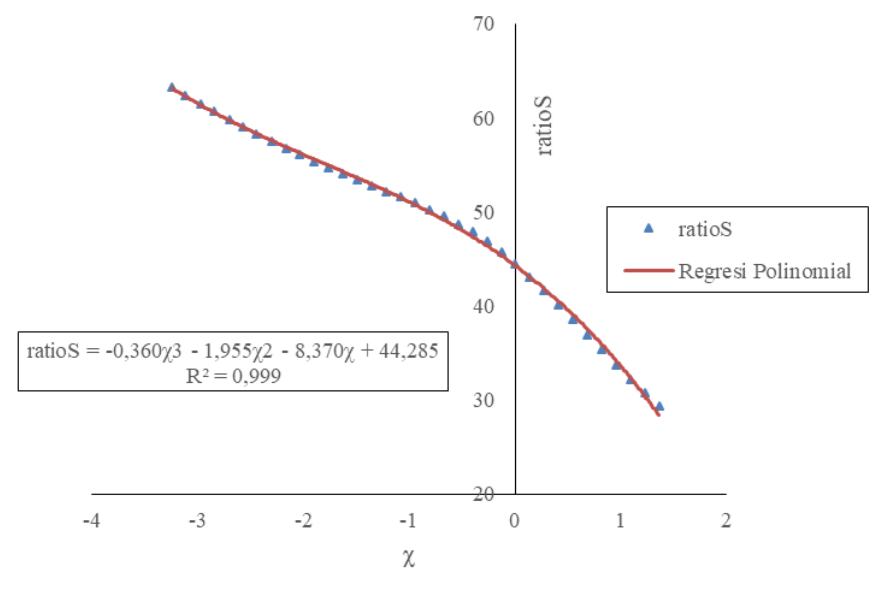

Gambar 10. Grafik hubungan antara ratioS dan $\chi$

Untuk memperkuat argumen dari hubungan yang sudah ditemukan, maka dilakukan pengujian pada satu batch operasi yang inputnya memiliki nilai distribusi ukuran partikel yang berbeda.

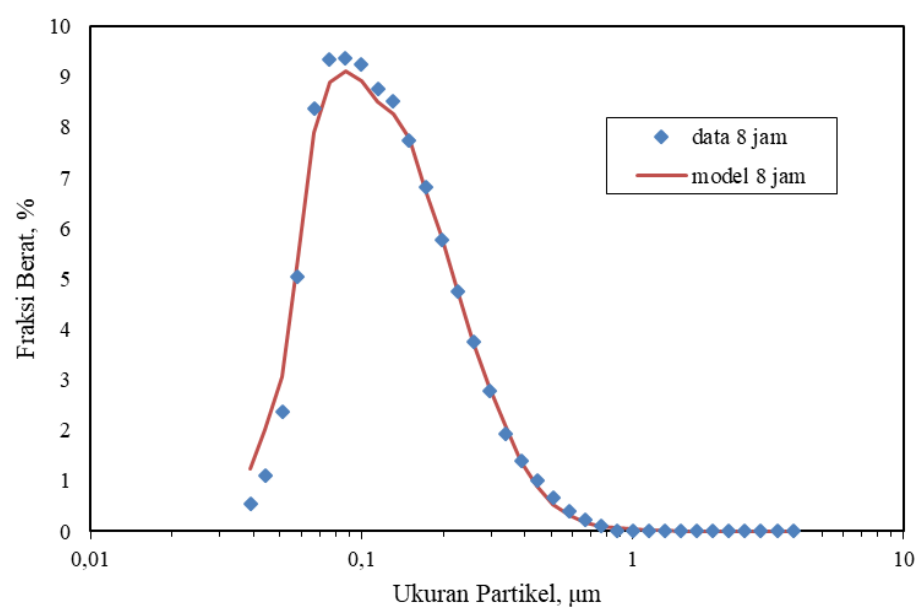

Gambar 11. Hasil pemodelan vs data $M M X-3$ untuk waktu grinding 8 jam dengan menggunakan persamaan korelasi 9.

Nilai Mean of Square Error dari pemodelan diatas sebesar 0,057 dan nilai R2 sebesar 0,995. Berdasarkan nilai Mean of Square Error yang relatif kecil dan kesesuaian visual antara data dan pemodelan, maka dapat disimpulkan bahwa korelasi yang didapatkan pada Persamaan 9 dapat dipergunakan untuk memprediksi hasil grinding pada mesin $M M X-3$.

\section{Kesimpulan}

Hasil penelitian menunjukkan bahwa dapat dibangun suatu hubungan yang memadai antara karakteristik mesin Lau Disperser skala laboratorium dengan mesin $M M X-3$ skala produksi yang ditunjukkan melalui Persamaan 9. Pendekatan neraca populasi dapat dipergunakan dengan baik untuk menganalisis fenomena yang terjadi pada kedua alat grinding yang ditinjau.

Metode kaji banding dan analisis yang dikembangkan melalui penelitian ini dapat dipergunakan sebagai titik awal (initial point) untuk pengembangan proses industrialisasi pada mesin skala produksi. Riset dengan bahan baku baru yang dikembangkan dapat dimulai dari skala laboratorium dan proses di skala produksi dapat disimulasikan terlebih dahulu untuk menentukan waktu yang diperlukan untuk mencapai kualitas tertentu dengan kapasitas produksi tertentu.

Catatan yang dapat diberikan terhadap hasil penelitian ini adalah lingkup persamaan hubungan yang hanya berlaku pada kondisi yang diobservasi. Walau demikian metode yang dijelaskan dapat 
dieksplorasi untuk diterapkan pada kondisi operasi yang berbeda dan bahkan pada jenis mesin grinding yang lain secara luas.

\section{Ucapan Terima Kasih}

Ucapan terima kasih dan penghargaan diberikan kepada Program Studi Magister Teknik Kimia, Fakultas Teknologi Industri, Institut Teknologi Bandung sebagai pihak yang memberikan bimbingan dan arahan pada penelitian ini.

\section{Daftar Pustaka}

[1] R. H. Leach dan R. J. Pierce, The printing ink manual. Netherland: Springer, 1993.

[2] T. C. Patton, Paint flow and pigment dispersion. Canada: John Wiley \& Sons, 1978.

[3] Buhler AG, Operating instruction agitator mill. Buhler AG, Swiss, 2016.

[4] Lau GmbH, Instruction manual for the lau-disperser. Lau GmbH, Hemer, 2016.

[5] R. H. Snow, T. Allen, B. J. Ennis, dan Litster, J.D., "Size reduction and size enlargement," dalam Perry's Chemical Engineer's Handbook, 7 ed., Mc Graw Hill, 1997, hlm. 1-56.

[6] V. Rao dan A. Datta, Development of Continuous-size Population Balance Model Using Discrete-size Particle Distribution. 2007.

[7] R. Tuunila, "Simulation of attrition bead mill and jet mill grinding," dipresentasikan pada IFAC Future Trends in Automation in Mineral and Metal Processing, Finlandia, 2000, vol. 33, hlm. 277-282.

[8] E. Petrakis dan K. Komnitsas, "Correlation between Material Properties and Breakage Rate Parameters Determined from Grinding Tests," Applied Sciences, vol. 8, no. 2, hlm. 220, Jan 2018.

[9] S. K. Kawatra, Ed., Advances in comminution. Littleton, Colo: Society for Mining, Metallurgy, and Exploration, 2006.

[10] E. Petrakis dan K. Komnitsas, "Improved Modeling of the Grinding Process through the Combined Use of Matrix and Population Balance Models," Minerals, vol. 7, no. 5, hlm. 67, Apr 2017.

[11] E. Petrakis, E. Stamboliadis, dan K. Komnitsas, "Identification of Optimal Mill Operating Parameters during Grinding of Quartz with the Use of Population Balance Modeling," KONA Powder and Particle Journal, vol. 34, no. 0, hlm. 213-223, 2017.

[12] P. Toneva dan W. Peukert, "Chapter 20 Modelling of Mills and Milling Circuits," dalam Handbook of Powder Technology, vol. 12, Elsevier, 2007, hlm. 873-911.

[13] V. Rodnianski, A. Levy, dan H. Kalman, "A new method for simulation of comminution process in jet mills," Powder Technology, vol. 343, hlm. 867-879, Feb 2019.

[14] J. C. E. Quist, DEM modelling and simulation of cone crushers and high pressure grinding rolls. Gothenburg, Sweden: Chalmers University of Technology, 2017.

[15] C. A. Pérez-Alonso dan J. A. Delgadillo, "DEM-PBM approach to predicting particle size distribution in tumbling mills," Mining, Metallurgy \& Exploration, vol. 30, no. 3, hlm. 145-150, Agu 2013.

[16] M. Wołosiewicz-Głąb, P. Pięta, D. Foszcz, S. Ogonowski, dan T. Niedoba, "Grinding Kinetics Adjustment of Copper Ore Grinding in an Innovative Electromagnetic Mill," Applied Sciences, vol. 8, no. 8, hlm. 1322, Agu 2018.

[17] Horiba Instrument, Inc, A guidebook to particle size analysis. California: Horiba Instruments, Inc., 2017.

[18] R. Purwadi, C. Niklasson, dan M. J. Taherzadeh, "Kinetic study of detoxification of dilute-acid hydrolyzates by $\mathrm{Ca}(\mathrm{OH})_{2}$," Journal of Biotechnology, vol. 114, hlm. 187-198, 2004. 